九州大学学術情報リポジトリ

Kyushu University Institutional Repository

Preparation of Anti-2,4-dinitrotoluene Monoclonal Antibody by Using Rat Medial Iliac Lymph Node Cells and Its Characterization Using Solid Phase Enzyme-linked Immunosorbent Assay

Nagatomo, Kazutaka

Laboratory of Food Analysis, Division of Food Biotechnology, Department of Bioscience and Biotechnology, Graduate School of Bioresource and Bioenvironmental Sciences, Kyushu University

Matsumoto, Kiyoshi

Laboratory of Food Analysis, Division of Food Biotechnology, Department of Bioscience and Biotechnology, Graduate School of Bioresource and Bioenvironmental Sciences, Kyushu University

Toko, Kiyoshi

Graduate School of Information Science and Electrical Engineering, Kyushu University

Miura, Norio

Art, Science and Technology Center for Cooperative Research, Kyushu University

https://doi.org/10.5109/14055

出版情報：九州大学大学院農学研究院紀要. 54 (1)，pp.173-178，2009-02-27. Faculty of Agriculture, Kyushu University

バージョン:

権利関係 : 


\title{
Preparation of Anti-2,4-dinitrotoluene Monoclonal Antibody by Using Rat Medial Iliac Lymph Node Cells and Its Characterization Using Solid Phase Enzyme-linked Immunosorbent Assay
}

\author{
Kazutaka NAGATOMO ${ }^{1}$, Kiyoshi MATSUMOTO*, \\ Kiyoshi TOKO ${ }^{2}$ and Norio MIURA ${ }^{3}$
}

\author{
Laboratory of Food Analysis, Division of Food Biotechnology, Department of Bioscience and \\ Biotechnology, Faculty of Agriculture, Kyushu University, \\ Fukuoka 812-8581, Japan \\ (Received November 4, 2008 and accepted December 5, 2008)
}

\begin{abstract}
Recent concern on international terrorism and weapons of mass destruction demands the development of novel analytical methods for identification and quantification of explosive molecules. 2,4-Dinitrotoluene $(2,4-\mathrm{DNT})$ is one of the decomposed compounds from 2,4,6-trinitrotoluene (TNT), a main explosive compound, and has high vapor pressure and life time than TNT. 2,4-DNT, thus, become a chemical signature of explosives. Monoclonal antibody against 2,4-DNT was prepared by using rat lymph node method. Four hybridoma cells which produce anti-DNPh antibody were produced out of 61 fusion positive cells. The best hybridoma cell (named DNPh-mAb2 cell) was selected for the production of monoclonal antibody (DNPhmAb2). The properties of DNPh-mAb2 were investigated such as cross-reactivity and affinity constant. The prepared DNPh-mAb2 has high avidity to 2,4-DNT compared with other nitroaromatic compounds except $N$-(2,4,6-tirinitrophenyl) glycine (TNP-Gly, ca. 50\%). TNP-Gly is not contained in general explosives, appearing no problem. The antibody has high affinity constant of $3.6 \times 10^{-6} \mathrm{~mol} \mathrm{~L}^{-1}$ to $2,4-\mathrm{DNT}$. The limit of detection of 2,4-DNT by indirect competitive ELISA was ca. $5 \mathrm{ng} \mathrm{mL}^{-1}$, showing suitable for 2,4-DNT detection.
\end{abstract}

\section{INTRODUCTION}

Recent concern on international terrorism and weapons of mass destruction demands the development of novel analytical methods for identification and quantification of explosive molecules. 2,4,6-Trinitrotoluene (TNT) is an important explosive compound and its detection is highly important in many areas including security and health of people, environmental and toxicological effects, landmine search, aviation security and prevention of terrorist attack (Yinon, 2002; Rouhi, 1997; Talmage et al., 1999; Miura et al., 2007). Thus, detection of TNT has been the main target for search of explosives. However, TNT released into the environment is decomposed and converted to dinitrotoluenes (DNTs) and aminodinitrotoluenes (ADNTs), among other products, by microorganisms, light, and heat (Kaplan, 1992; Borch and Gerlach, 2004; Becher, 1995).

Among them, 2,4-dinitrotoluene (2,4-DNT) is contained in TNT as a manufacturing impurity and it has much higher vapor pressure and life time than TNT. Therefore, 2,4-DNT may become the most common "chemical signature" of explosive compounds (Jenkins et al., 2001).

Explosive-related compounds have been measured

\footnotetext{
Laboratory of Food Analysis, Division of Food Biotechnology, Department of Bioscience and Biotechnology, Graduate School of Bioresource and Bioenvironmental Sciences, Kyushu University

${ }^{2}$ Graduate School of Information Science and Electrical Engineering, Kyushu University, Fukuoka, 819-0395, Japan

${ }^{3}$ Art, Science and Technology Center for Cooperative Research, Kyushu University, Kasuga, Fukuoka, 816-8580, Japan

* Corresponding author (E-mail: kmatsu@agr.kyushu-u.ac.jp)
}

by using HPLC or other instrumental analytical devices (Borch and Gerlach, 2004; Ahmad and Roberts, 1995). These instrumental analyses, however, require tedious pre-treatments such as extraction from samples (Halasz et al., 2002). On the other hand, detection methods using an antigen-antibody reaction, such as enzyme-linked immunosorbent assay (ELISA) and fluorescent and chemiluminescent immunosensors, are more useful and are able to detect ng $\mathrm{mL}^{-1}$ levels of explosive compounds (Goldman et al., 2003; Green et al., 2002; Wilson et al., 2003).

One of the key components for successful immunoassay is how high affinity antibodies can be made for the target molecules, such as TNT and 2,4-DNT. For this purpose, we have engaged in producing polyclonal and monoclonal antibodies for TNT and 2,4-DNT (Sakai et al., 2003; Matsumoto et al., 2005; Nagatomo et al., submitting). Recently, a novel method was developed for preparation of rat monoclonal antibodies by using rat medial iliac lymph node cells. This method has some superiority such as: 1) no necessity of booster injection, 2) short time after first injection (ca. 2 weeks), 3) high rate of appearance of positive hybridomas (Kishiro et al., 1995; Sado et al., 1995; Sado et al., 2006).

In this paper, we prepared anti-2,4-dinitrotoluene monoclonal antibody by using rat medial iliac lymph node cells and characterized its properties using solid-phase enzyme-linked immunosorbent assay (ELISA).

\section{MATERIALS AND NETHODS}

\section{Materials and apparatus}

Bovine serum albumin (BSA), $N$-hydroxysuccinimide (NHS), $o$-phenylene diamine $(o-P D)$ and gelatin were 
obtained from Nacalai Tesque, Inc. (Kyoto, Japan). Ovalbumin (OVA), 2,4-dinitrotoluene (2,4-DNT), $N$-(2,4-dinitrophenyl) glycine (2,4-DNP-Gly), 2,4-dinitrophenylacetic acid (2,4-DNPA) and 1-ethyl-3-(3dimethyl aminopropyl) carbodiimide (EDC) were obtained from Sigma (St. Louis, MO, USA). 2,6-Dinitrotoluene (2,6-DNT), 2,4-dinitrobenzoic acid (2,4-DNBA), 1,2-diaminoethane, 1,4-diaminobutane, 1,8-diaminooctane, 1,10-diaminodecane and GIT medium were obtained from Wako Pure Chemicals Ind., Ltd. (Osaka, Japan). 1,3-Dinitrobenzene (1,3-DNB) and 2,4,6-trinitrophenol (TNP-OH) were purchased from Kishida Chemical Co., Ltd. (Osaka, Japan). N-(2,4,6trinitrophenyl) glycine (TNP-Gly) was obtained from Funakoshi Co. (Tokyo, Japan). 2,4-Dinitrophenol (2,4-DNP-OH) and 2,4-dinitroaniline (2,4-DNA) were from Riedel-de Haen (Seelze, Germany). 2,4-Dinitrobenzenesulfonate sodium salt (2,4-DNBS) was from Research Chemicals (Toronto, Canada). 2,4,6-Trinitrotoluene (TNT) and 2-methyl-1,5-diaminopentane were from Supelco (Bellefonte, PA, USA) and Tokyo Kasei Co. Ltd. (Tokyo, Japan), respectively. Freund's complete adjuvant was obtained from Difco (Detroit, MI, USA). Sevofrane was from Maruishi Pharmaceutical Co. Ltd. (Osaka, Japan). Fetal bovine serum (FBS) and BM-condimed H1 were from Gibco (OK, USA) and Roche (Basel, Switzerland), respectively. Horse radish peroxidase labeled polyclonal rabbit antirat immunoglobulin G (HRP-anti-rat IgG) was from Daco Japan Co. (Tokyo, Japan). 2,4-DNPh-KLH (keyhole limpet hemocyanin) conjugate was purchased from Merck (Dalmstadt, Germany) as DNPh-KLH-400, which was guaranteed the hapten numbers more than 400-mol per mol-KLH. The Hi Trap Protein G column and PD-10 column were purchased from Amersham Bioscience (Piscataway, NJ, USA). All other reagents were of analytical-reagent grade. All buffer solutions were prepared using water purified with a Milli-Q filter (Millipore, Bedford, MA, USA).

ELISA measurements were performed using 96-well immunoplates (NUNC, No. 446612, Roskilde, Denmark) and a microplate reader (Wallac 1420, Perkin Elmer Life Science Japan, Tokyo, Japan). Spectrophotometric measurements were performed using a Shimadzu Multi Spec 1500 (Kyoto, Japan)

\section{Immunization of rats}

Rats, anesthetized with sevofrane, were immunized with DNPh-KLH-400 conjugates according to the following procedures. Conjugates dissolved in phosphate buffered saline (PBS, $1 \mathrm{mg} \mathrm{mL}^{-1}$ ) and an equal volume of Freund's complete adjuvant were emulsified in two 2-mL glass syringes with a three-way stopcock. After emulsification was completed, the emulsion was sucked in one $\mathrm{mL}$ of plastic syringe attached with $25 \mathrm{G} \times 1$ " needle.

Nine-week-old female WKY rats (Charles River Japan, Inc., Yokohama) were injected intramuscularly at the right and left tail base with the prepared emulsion ( $0.2 \mathrm{~mL}$ in total). Rats were kept in plastic cages containing wood shavings for bedding. All animal experiments were conducted under the control of the guideline for Animal Experiment in Kyushu University and the Law (No. 105) and Notification (No. 6) of the Government.

On days, 0, 7, 14 and 16, the rats were bled from tail veins, and the antisera were collected by centrifugation of the blood samples. The antisera were tested by directELISA. Ninety-six-well immunoplates were coated with $100 \mu \mathrm{L}$ of DNPh-KLH-400 conjugates or DNPh-C8-OVA conjugates (both of concentration: $10 \mu \mathrm{g} \mathrm{m} \mathrm{m}^{-1}$ in PBS) overnight at room temperature. The plates were then washed three times with PBS containing 0.05\% Tween 20 (PBST) and treated with $150 \mu \mathrm{L}$ of $1 \%$ gelatin for $1 \mathrm{~h}$ at room temperature, and again washed three times with PBST and reacted with antisera at ten different dilutions (1/100-1/51200 in PBS), which were added to the wells ( $50 \mu \mathrm{L}$ to each well) and incubated for $1.5 \mathrm{~h}$ at room temperature. The plates were washed again three times with PBST, and the solution of HRP-labeled anti-rat IgG $\left(1 \mu \mathrm{g} \mathrm{mL}^{-1}\right)$ was added (100 $\mu \mathrm{L}$ to each well) and incubated for $1 \mathrm{~h}$ at room temperature. The plates were washed again, and $150 \mu \mathrm{L}$ of the substrate solution (0.4 $\mathrm{mg} \mathrm{mL}^{-1}$ of $o-\mathrm{PD}$ and $0.4 \mu \mathrm{L} \mathrm{mL}^{-1}$ of $30 \% \mathrm{H}_{2} \mathrm{O}_{2}$ in PBS) was added to each well and incubated for $30 \mathrm{~min}$ at room temperature. After the reaction, $50 \mu \mathrm{L}$ of $3 \mathrm{~mol} \mathrm{~L}^{-1}(\mathrm{M})$ sulfuric acid was added to terminate the enzyme reaction, and then the absorbance at $490 \mathrm{~nm}$ was measured. The rats were bled without boost injection for 16 days for obtaining iliac lymph cells and 21 days for obtaining polyclonal antibodies.

\section{Cell fusion}

A mouse myeloma cell line, Sp2/0-Ag14 (Dainihon Sumitomo Pharmacy), was used for cell fusion. The rats were sacrificed at 16 days after first injection. The lymph node cells were passed through a 200-mesh stainless steel wire mesh. The cells were suspended in GIT medium containing 10\% FBS and centrifuged at $1000 \mathrm{rpm}$ for $2 \mathrm{~min}$ and rinsed with the $5 \mathrm{~mL}$ of same medium. The collected lymph node cells were mixed with myeloma cells in a ratio of 10:1 ( $2 \times 10^{7}$ lymph cells and $2 \times 10^{6}$ myeloma cells) and centrifuged. One $\mathrm{mL}$ of polyethylene glycol 1500 was added drop by drop over 1 min to the cell pellet. After that, $4.5 \mathrm{~mL}$ of Dulbecco's modified eagle medium (DMEM) (Gibco, USA) was slowly added over $3 \mathrm{~mL}$ and then another $4.5 \mathrm{~mL}$ was added over $2 \mathrm{~min}$. After centrifugation (1600 rpm, $2 \mathrm{~min}$ ), the supernatant was removed and $50 \mathrm{~mL}$ of HAT selection medium was added.

The HAT selection medium was GIT medium containing 10\% FBS, 10\% BM-condimed H1, 0.16 mM hypoxanthine, $0.016 \mathrm{mM}$ thymidine and $0.4 \mu \mathrm{M}$ aminopterin. The resulting suspension was subjected to cell culture with 96-well plates. Suspensions containing HAT selection medium (150 $\mu \mathrm{L}$ to each well) were added to each well. On day 9, supernatants were collected and screened.

\section{Serum antibody titers and screening assay}

The supernatants were screened for production of DNPh-antibody by indirect ELISA. ELISA plates were 
coated with $100 \mu \mathrm{L}$ of DNPh-C8-OVA conjugate (10 $\mu \mathrm{g}$ $\mathrm{mL}^{-1}$ ) overnight at room temperature. The plates were washed and blocked with 1\% BSA for $1 \mathrm{~h}$ at room temperature. The plates were washed and $50 \mu \mathrm{L}$ of the supernatant of each cultured well were added to each well. One series of experiments was performed to check the association of supernatants (antibodies) to the coating conjugates. Another series of experiments was performed to check whether the supernatants (antibodies) will be inhibited with free 2,4-DNT as follows: after the addition of supernatant, $50 \mu \mathrm{L}$ of $2,4-\mathrm{DNT}$ solution was added at the final concentration of $1 \mu \mathrm{g} \mathrm{mL}^{-1}$. The subsequent procedures for both experiments were almost the same as above. The cells, which were confirmed the production of DNPh-antibody and the ability of association toward free 2,4-DNT, were suspended in GIT medium containing 10\% FBS. The suspensions were subjected to the limit dilution methodology, and the screening and cloning were repeated for three times, and then monoclonal antibody producing hybridomas were established.

\section{Preparation of coating antigen-protein conjugates}

The coating antigen-protein conjugates (DNPh-OVA and DNPh-Cx-OVAs) were prepared according to our previous report (Nagatomo et al., submitting) with a little modification, except DNPh-blanched C6-OVA. DNPh-blanched C6-OVA conjugate was prepared as follows: in a solution of $25 \mathrm{mM}$ borate buffer ( $\mathrm{pH}$ 8.0, $3 \mathrm{~mL}$ ), $53 \mathrm{mg}$ of OVA and $12.8 \mathrm{mg}$ of NHS were dissolved, and then $312 \mathrm{mg}$ of EDC was added to the solution and stirred $1 \mathrm{~h}$ at room temperature. 2-Methyl-1,5-diaminopentane (3.5 mL, liquid) was gently added to the reaction mixture and stirred over night. The mixture was dialyzed against five changes of $\mathrm{H}_{2} \mathrm{O}$ at room temperature and centrifuged. The supernatant was lyophilized to produce blanched-C6-OVA. After the lyophilized powder (12 mg) was dissolved in $1 \mathrm{~mL}$ of $4 \% \mathrm{NaHCO}_{3}$ solution, $1 \mathrm{~mL}$ of 2,4-DNBS solution ( $40 \mathrm{mg} \mathrm{mL}^{-1}$ ) was added to the solution and stirred over night at room temperature. The reaction mixture was dialyzed against $\mathrm{H}_{2} \mathrm{O}$ and lyophilized to produce DNPh-blanched C6-OVA conjugate.

\section{Association properties of monoclonal anti-DNPh- KLH-400 antibody to various kinds of nitroaro- matic compounds}

The avidity of anti-DNPh-KLH-400 antibody to nitroaromatic compounds was investigated by indirect competitive ELISAs using DNPh-C8-OVA as a coating antigen-protein conjugate. The $\mathrm{IC}_{50}$ was defined as the concentration of added DNPh- or TNPh-derivative that yields 50\% inhibition compared with no inhibition (100\%). Molar cross-reactivities were related to 2,4-DNT (100); namely, all molar cross-reactivities were determined in relation to the 2,4-DNT standard inhibition curve. The molar cross-reactivity was calculated using the $\mathrm{IC}_{50}$ of each derivative according to the following equation (Weiler and Zenk, 1976):

$$
\mathrm{CR}=\left(\mathrm{IC}_{50} * / \mathrm{IC}_{50}\right) \times 100
$$

where CR is molar cross-reactivity [\%], $\mathrm{IC}_{50} *$ is the $\mathrm{IC}_{50}$ of the 2,4-DNT standard [M], and $\mathrm{IC}_{50}$ is the $\mathrm{IC}_{50}$ of derivatives or related compounds $[\mathrm{M}]$.

\section{RESULTS AND DISCUSSION}

\section{Immunization property}

The results of the immunization of the rat with DNPh-KLH-400 conjugate are shown in Fig. 1. The antisera titers of the immunized rat increased, especially after 14 days after injection. All the blood from the rat was collected at day 16 or 21 . The concentration of the antiDNPh-KLH-400 antibody after Protein G treatment was estimated to be about $5 \mathrm{mg} \mathrm{mL}^{-1}$ of serum, standardized as human IgG. The antisera recognized not only the KLH protein but also the DNPh-moiety of DNPh-KLH-400 conjugates, because the titers using DNPh-KLH conjugate (Fig. 1-a) and DNPh-C8-OVA conjugates (Fig. $1-b)$ as coating antigen were almost the same. (a)

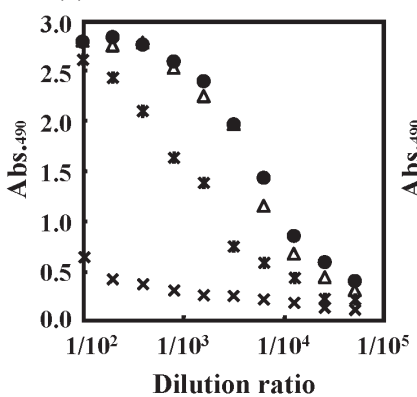

(b)

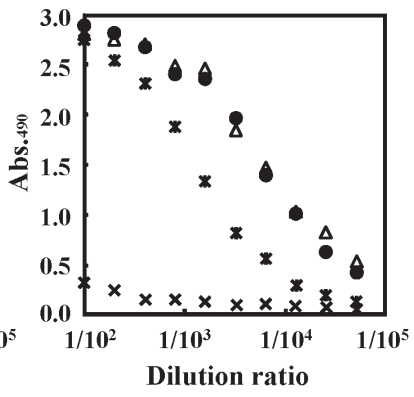

Fig. 1. Time course of antigen-specific antibody concentration in sera from rats immunized with DNPh-KLH-400 conjugate. (a) Using DNPh-KLH-400 conjugate as coating conjugate. (b) Using DNPh-C8-OVA conjugate as coating antigen. The concentration of each coating conjugates was $10 \mu \mathrm{g} \mathrm{mL}{ }^{-1}$. Symbols are as follows: $\times$, Before immunization; $\boldsymbol{*}$, Seven days after immunization; $\triangle$, Fourteen days after immunization; , Sixteen days after immunization.

\section{Appearance of monoclonal antibody hybridoma}

The appearance of the hybridoma cells which produce monoclonal anti-DNPh antibody (DNPh-mAb) was four cells of 61 fusion positive cells. We denoted the hybridomas as DNPh-mAb1 cell to DNPh-mAb4 cell. The inhibition profiles by the indirect competitive ELISA are shown in Fig. 2 along with that of rat anti-DNPhKLH-400 polyclonal antibody (DNPh-pAb). From Fig. 2, we selected the DNPh-mAb2 hybridoma as a best one, and used hereafter.

\section{Association properties of monoclonal anti- DNPh-400 antibody to various kinds of nitroaro- matic compounds}

The avidity of the prepared antibody to nitroaromatic compounds was evaluated by indirect competitive ELISAs. The coating antigen-protein conjugate was DNPh-C8-OVA. Midpoints $\left(\mathrm{IC}_{50}\right)$ and molar cross-reactivity are listed in Table 1 . The skeletal structure of the nitroaromatic compounds is shown in Fig. 3 and the 


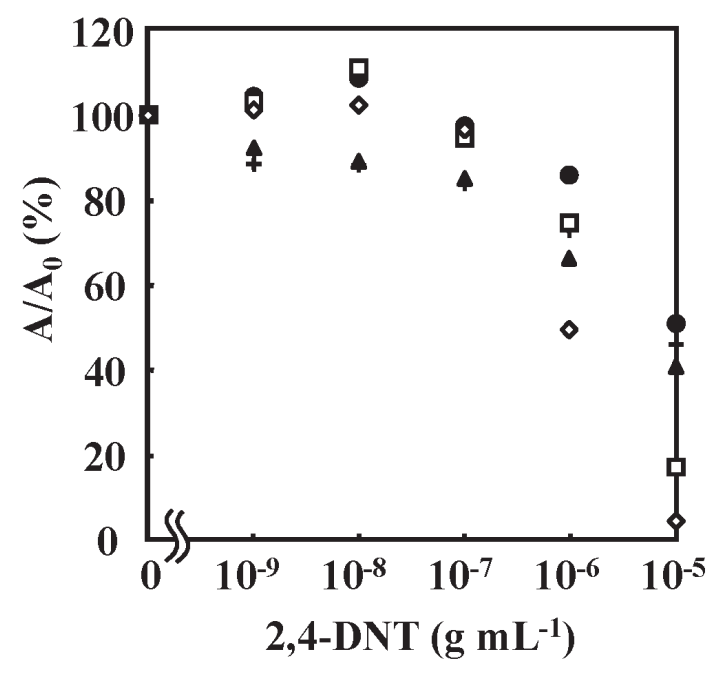

Fig. 2. Binding profiles of monoclonal antibodies from established hybridomas. The concentration of coating conjugate (DNPh-C8-OVA) was $10 \mu \mathrm{g} \mathrm{mL}^{-1}$. Symbols are as follows: $\square$, DNPh-mAb1; $\diamond$, DNPh-mAb2; +, DNPh-mAb3; DNPh-mAb4; $\boldsymbol{\Delta}$, DNPh-pAb.

chemical groups of the side chain $\left(R_{1}, R_{2}, R_{3}\right.$ and $\left.R_{4}\right)$ are shown in Table 1. As shown in Table 1, 2,4-DNP-OH, 2,4-DNBA and 2,4-DNPA showed cross-reactivity of less than $2 \%$ or no association, when the molar cross-reactivity of 2,4-DNT was set as 100\%. These results show that the monoclonal anti-DNPh-400 antibody (DNPhmAb2) discriminates the side chain groups of $-\mathrm{OH}$, $-\mathrm{COOH}$ and $-\mathrm{CH}_{2}-\mathrm{COOH}$ moieties on the benzene ring. $2,6-$ DNT showed about $18 \%$ of cross-reactivity, showing that this DNPh-mAb2 discriminates the position of nitro group but also recognizes a little for dinitrophenylcompounds.1,3-DNB, 2,4-DNP-Gly and 2,4-DNA showed the cross-reactivity ranging from $12 \%$ to $39 \%$, showing that dinitro-groups are recognized a little and recogni-

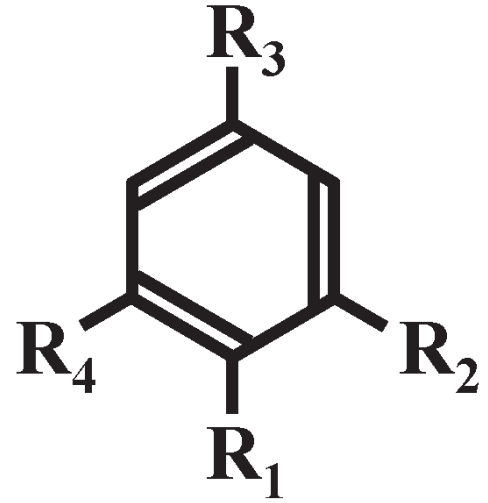

Fig. 3. Skeletal structure of the nitroaromatic compounds.

tion of $-\mathrm{NH}_{2}$ group on the benzene ring is a little higher. Recognition to TNPh-Gly was about 50\%, while those to TNT and TNP-OH were lower about $21 \%$ and $6 \%$. The reason is not clear but this DNPh-mAb2 would recognize trinitro-compounds. The low recognition of TNP-OH would be caused by the - $\mathrm{OH}$ group on the benzene ring like 2,4-DNP-OH. TNP-Gly is not contained in explosives and decomposition compounds, so the recognition to this compound produces no problem. Overall, the produced DNPh-mAb2 has relatively high selectivity to 2,4-DNT compared with other nitroaromatic compounds and useful for detection of 2,4-DNT.

\section{Optimization of the spacer structure of the coat- ing antigen-protein conjugates}

Kim et al. (2003) reported that heterology in the spacer structure of the coating antigen produced a remarkable improvement in the sensitivity of indirect competitive ELISA. According to our previous research (Nagatomo et al. submitting), the spacer structure on

Table 1. Cross reactivities of anti-DNPh mAb2 for 2,4-DNT relevant compounds

\begin{tabular}{|c|c|c|c|c|c|c|}
\hline Compound & $\mathrm{R}_{1}$ & $\mathrm{R}_{2}$ & $\mathrm{R}_{3}$ & $\mathrm{R}_{4}$ & $\mathrm{IC}_{50}(\mathrm{M})$ & Cross reactivity (\%) \\
\hline $\begin{array}{c}\text { 2,4-dinitrotoluene } \\
(2,4-\mathrm{DNT})\end{array}$ & $\mathrm{CH}_{3}$ & $\mathrm{NO}_{2}$ & $\mathrm{NO}_{2}$ & $\mathrm{H}$ & $5.0 \times 10^{-7}$ & 100 \\
\hline $\begin{array}{c}\text { 2,4,6-trinitrophenyl-glycine } \\
\text { (TNP-Gly) }\end{array}$ & $\mathrm{NH}-\mathrm{CH}_{2}-\mathrm{COOH}$ & $\mathrm{NO}_{2}$ & $\mathrm{NO}_{2}$ & $\mathrm{NO}_{2}$ & $1.0 \times 10^{-6}$ & 50 \\
\hline $\begin{array}{c}\text { 2,4-dinitroaniline } \\
\text { (2,4-DNA) }\end{array}$ & $\mathrm{NH}_{2}$ & $\mathrm{NO}_{2}$ & $\mathrm{NO}_{2}$ & $\mathrm{H}$ & $1.3 \times 10^{-6}$ & 39 \\
\hline $\begin{array}{l}\text { 1,3-dinitrobenzene } \\
\text { (1,3-DNB) }\end{array}$ & $\mathrm{H}$ & $\mathrm{NO}_{2}$ & $\mathrm{NO}_{2}$ & $\mathrm{H}$ & $2.3 \times 10^{-6}$ & 22 \\
\hline $\begin{array}{c}\text { 2,4,6-trinitrotoluene } \\
\text { (TNT) }\end{array}$ & $\mathrm{CH}_{3}$ & $\mathrm{NO}_{2}$ & $\mathrm{NO}_{2}$ & $\mathrm{NO}_{2}$ & $2.4 \times 10^{-6}$ & 21 \\
\hline $\begin{array}{c}\text { 2,6-dinitrotoluene } \\
(2,6-\mathrm{DNT})\end{array}$ & $\mathrm{CH}_{3}$ & $\mathrm{NO}_{2}$ & $\mathrm{H}$ & $\mathrm{NO}_{2}$ & $2.8 \times 10^{-6}$ & 18 \\
\hline $\begin{array}{l}\text { 2,4-dinitrophenyl-glycine } \\
\text { (2,4-DNP-Gly) }\end{array}$ & $\mathrm{NH}-\mathrm{CH}_{2}-\mathrm{COOH}$ & $\mathrm{NO}_{2}$ & $\mathrm{NO}_{2}$ & $\mathrm{H}$ & $4.2 \times 10^{-6}$ & 12 \\
\hline $\begin{array}{c}2,4,6,- \text { trinitrophenol } \\
\text { (TNP-OH) }\end{array}$ & $\mathrm{OH}$ & $\mathrm{NO}_{2}$ & $\mathrm{NO}_{2}$ & $\mathrm{NO}_{2}$ & $8.6 \times 10^{-6}$ & 6 \\
\hline $\begin{array}{c}\text { 2,4-dinitrobenzoic acid } \\
(2,4-\mathrm{DNBA})\end{array}$ & $\mathrm{COOH}$ & $\mathrm{NO}_{2}$ & $\mathrm{NO}_{2}$ & $\mathrm{H}$ & $3.2 \times 10^{-5}$ & 1 \\
\hline $\begin{array}{l}\text { 2,4-dinitrophenylacetic acid } \\
(2,4-\mathrm{DNPA})\end{array}$ & $\mathrm{CH}_{2}-\mathrm{COOH}$ & $\mathrm{NO}_{2}$ & $\mathrm{NO}_{2}$ & $\mathrm{H}$ & $6.2 \times 10^{-5}$ & 1 \\
\hline $\begin{array}{c}\text { 2,4-dinitrophenol } \\
(2,4-\mathrm{DNP}-\mathrm{OH})\end{array}$ & $\mathrm{OH}$ & $\mathrm{NO}_{2}$ & $\mathrm{NO}_{2}$ & $\mathrm{H}$ & Not detected & - \\
\hline
\end{tabular}


the coating antigen-protein conjugate affects the sensitivity of 2,4-DNT detection. So, we examined the effect of spacer structure having DNPh-OVA DNPh-C8-OVA including DNPh-blanched C6-OVA on the sensitivity of DNT detection. Judging from the experimental results, we selected DNPh-C4-OVA as a best coating antigen, although the DNPh-C2-OVA coating antigen was almost the same (data not shown).

\section{Detection of 2,4-DNT by indirect competitive ELISA}

Figure 4 shows the standard curve of inhibition by 2,4-DNT using DNPh-mAb2 in indirect competitive ELISA along with the inhibition curve using rat antiDNPh-KLH-400 polyclonal antibody (DNPh-pAb). The coating antigen-protein conjugates were DNPh-C4-OVA and DNPh-C8-OVA for DNPh-mAb2 and DNPh-pAb, respectively. As shown in Fig. 4, 2,4-DNT was detected at the concentration of $c a .5 \mathrm{ng} \mathrm{mL}^{-1}$, when more than

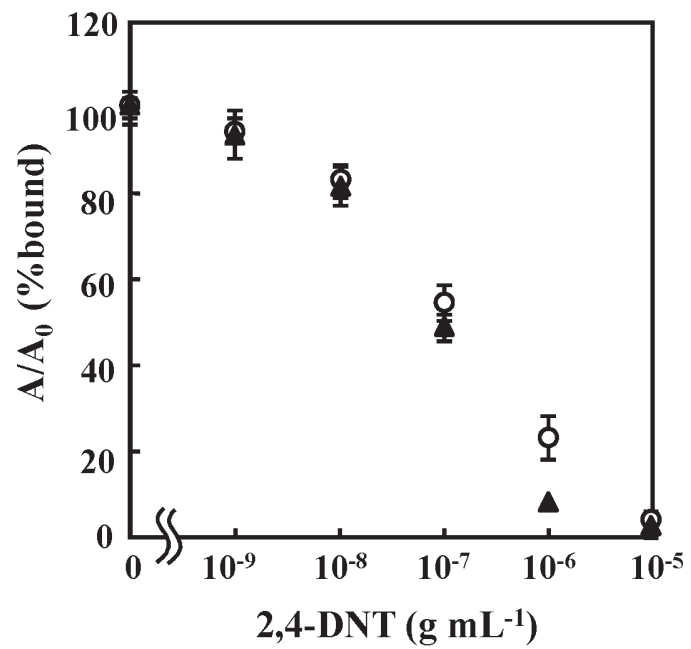

Fig. 4. Standard curve of 2,4-DNT in indirect competitive ELISA. The results are shown as mean values $(n=6)$ and error bars represent standard divisions. The concentrations of coating conjugate (DNPh-C4-OVA for DNPh-mAb2 and DNPhC8-OVA for DNPh-pAb respectively.) were $0.5 \mu \mathrm{g} \mathrm{mL}^{-1}$. Symbols are as follows: $\boldsymbol{\Delta}, \mathrm{DNPh}-\mathrm{mAb} 2 ; \bigcirc, \mathrm{DNPh}-\mathrm{pAb}$. (a)

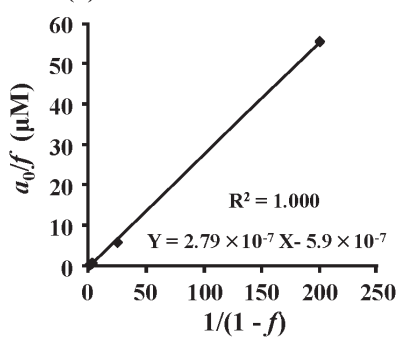

(b)

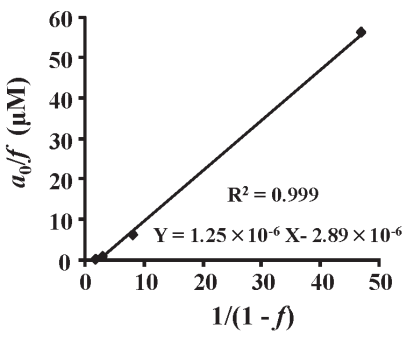

Fig. 5. Estimation of dissociation constants by Seligman's method using data from Fig. 4. (a) Using DNPh-mAb2 as competing antibody. (b) Using DNPh-pAb as competing antibody. Seligman's Formula; $a_{0} / f=\mathrm{K}_{\mathrm{D}} /(1-f)+i_{0} ; v=\left(A_{0}-A_{i}\right) / A_{0}$ where $A_{0}$ is the absorbance without $2,4-\mathrm{DNT}$ and $A_{i}$ is the absorbance with 2,4-DNT; $a_{0}$, initial concentration of 2,4-DNT; $f=\sqrt{v} ; i_{0}$, initial antibody concentration.
$15 \%$ decrease of the signal from non-analyte (100\%) was chosen as a detection limit. The affinity constants between free 2,4-DNT and anti-DNPh-KLH antibodies (monoclonal and polyclonal) were also estimated by using Seligman's method (Seligman, 1994) using the data of Fig. 4, and the results are shown in Fig. 5. The evaluated values were $\mathrm{K}_{\mathrm{A}}=3.6 \times 10^{6} \mathrm{M}^{-1}$ and $\mathrm{K}_{\mathrm{A}}=8.0 \times 10^{5} \mathrm{M}^{-1}$ for $\mathrm{DNPh}-\mathrm{mAb} 2$ and $\mathrm{DNPh}-\mathrm{pAb}$, respectively. These results show that monoclonal antibody has better association property than that of polyclonal antibody.

\section{CONCLUSIONS}

Monoclonal antibody against 2,4-DNT was successfully prepared by using rat lymph node method. Four hybridoma cells which produce anti-DNPh antibody were produced out of 61 fusion positive cells. The best hybridoma cell (DNPh-mAb2 cell) were selected for the production of monoclonal antibody (DNPh-mAb2). The properties of DNPh-mAb2 was investigated such as cross-reactivity and affinity constant. The prepared DNPh-mAb2 has high selectivity to 2,4-DNT compared with other nitroaromatic compounds and high affinity constant of $3.6 \times 10^{6} \mathrm{M}^{-1}$ to $2,4-\mathrm{DNT}$. The limit of detection of 2,4-DNT by indirect competitive ELISA was $c a$. $5 \mathrm{ng} \mathrm{mL}^{-1}$, showing suitable for 2,4-DNT detection.

\section{ACKNOWLEDGEMENTS}

This work was partly supported by a Grant-in-Aid from JST (Japan Science and Technology Corporation).

\section{REFERENCES}

Ahmad F., and D. J. Roberts 1995 Use of narrow-bore high-performance liquid chromatography-diode array detection for the analysis of intermediates of the biological degradation of 2,4,6-trinitrotoluene. J. Chromatogr. A, 693: 167-175

Becher, N. M. 1995 Fate of selected high explosives in the environment: A literature review $C I C-14$ report collection

Borch T., and R. Gerlach 2004 Use of reversed-phase high-performance liquid chromatography-diode array detection for complete separation of 2,4,6-trinitrotoluene metabolites and EPA Method 8330 explosives: influence of temperature and ion-pair reagent. J. Chromatogr. A, 1022: 83-94

Goldman E. R., A. Hayhurst, B. M. Lingerfelt, B. L. Iverson, G. Georgiou, and G. P. Anderson 2003 2,4,6-Trinitrotoluene detection using recombinant antibodies. J. Environ. Monit. 5: $380-383$

Green T. M., P. T. Charles, and G. P. Anderson 2002 Detection of 2,4,6-trinitrotoluene in sea water using a reversed-displacement immunosensor. Anal. Biochem., 310: 36-41

Halasz A., C. Groom, E. Zhou, L. Paquet, C. Beaulier, S. Deschamps, A. Corrveau, S. Thiboutot, G. Ampleman, C. Dubois, and J. Hawari 2002 Detection of explosives and their degradation products in soil envieronments. J. Chromatogr. A, 963: 411-418

Jenkins T. F., D. C. Leggett, P. H. Miyares, H. E. Walsh, T. T. Ranney, J. H. Cragin, and V. George 2001 Chemical signature of TNT-filled landmines. Talanta, 54: 501-503

Kaplan, D. L. 1992 Biological degradation of explosives and chemical agents. Current Opinion Biotechnology, $\mathbf{3}$ 253-260

Kim Y. J., Y. A. Cho, H-S. Lee, Y. T. Lee, S. T. Gee, and B. D. Hammock 2003 Immunoassay of organophosphorous pesti- 
cides and effect of heterology in hapten spacer arm length on immunoassay sensitivity. Anal. Chim. Acta, 475: 85-96

Kishiro, Y., M. Kagawa, I. Naito, Y. Sado 1995 A Novel Method of Preparing Rat-Monoclonal Antibody-Producing Hybridomas by Using Rat Medial Iliac Lymph Node Cells. Cell Struct. Funct., 20: 151-156

Matsumoto K., A. Torimaru, S. Ishitobi, T. Sakai, H. Ishikawa, K. Toko, N. Miura, and T. Imato 2005 Preparation and characterization of a polyclonal antibody from rabbit for detection of trinitrotoluene by a surface plasmon resonance biosensor. Talanta, 68: 305-311

Miura N., D. R. Shankaran, T. Kawaguchi, K. Matsumoto, and K. Toko 2007 High-performance Surface Plasmon Resonance Immunosensors for TNT Detection. Electochem., 75: 13-22

Nagatomo, K., K. Matsumoto, S. Ishitobi, M. Koga, K. Ikeda, K. Toko, N. Miura (Submitting) Preparation of Antidinitrotoluene Polyclonal Antibodies and Effect of the Hapten Spacer Length in Coating Antigen on Immunoassay Sensitivity. J. Fac. Agr., Kyushu Univ.

Rouhi A. M. 1997 Landmines: Horrors begging for solutions. Chem. Eng. News, 75:14-22

Sado, Y., M. Kagawa, Y. Kishiro, K. Sugihara, I. Naito, J. M. Seyer, M. Sugimoto, T. Oohashi, Y. Ninomiya 1995 Establishment by the rat lymph node method of epitope-defined monoclonal antibodies recognizing the six different $\alpha$ chains of human type IV collagen. Histochem. Cell Biol., 104: 267-275

Sado, Y. S. Inoue, Y. Tomono, and H. Omori 2006 Lymphcytes from Enlarged Iliac Lymph Nodes as Fusion Partners for the Production of Monoclonal Antibodies after a Signle Tail Base Immunization Attempt. Acta Histochem. Cytochem., $\mathbf{3 9}$ $89-94$

Sakai T., A. Torimaru, K. Shinahara, N. Miura, T. Imato, K. Toko, and K. Matsumoto 2003 Preparation of a Polyclonal Antibody and a Bioassay for Nitroaromatic Compounds by an Enzyme-Linked Immunosorbent Assay Technique and a Surface Plasmon Resonance Immunosensor. Sens. Mater., 15: $439-452$

Seligman S. T. 1994 Influence of solid-phase antigen in competition enzyme-linked immunosorbent assays (ELISAs) on calculated antigen-antibody dissociation constants. Immunol. Methods, 168: 101-110

Talmage S. S, D. M. Opresko, C. S. Maxwell, C. J. E. Welsh, F. M. Cretella, P. H. Reno, and F. B. Daniel 1999 Nitroaromatic munition compounds: environmental effects and screening values. Rev. Envion. Contam. Toxicol., 161: 1-156

Weiler E. W., and M. H. Zenk 1976 Radioimmunoassay for the determination of digoxin and related compounds in Digitalis lanata. Phytochem., 15: 1537-1545

Wilson R., C. Clavering, and A. Hutchinson 2003 Electrochemiluminescence enzyme immunoassay for TNT Analyst, 128: 480-485

Yinon, J. 2002 Field detection and monitoring of explosives. Trends Anal. Chem., 21: 292-301 